\title{
Seasonal occurrence of Dinophysis sp. along the French coast between 1983 and 1987
}

\author{
Patrick Lassus, Michèle Bardouil, Jean-Paul Berthomé, Pierre Maggi, \\ Philippe Truquet and Loïc Le Déan
}

IFREMER, Centre de Nantes, BP $n^{\circ}$ 1049, 41037 Jantes Cedex (France).

Received $\Lambda$ pril 21, 1988; accepted July 20, 1988.

Lassus P., M. Bardouil, J.-P. Berthomé, P. Maggi, P. Truquet, L. Le Déan. Aquat. Liting Resour., $1988,1,155-164$.

Abstract On the basis of hydrological and biological data collected between 1983 and 1987 along the French coast, and especially in the southern approaches to Brittany, it has been possible to compare different parameters in an attempt to explain the seasonal variations of a toxic dinoflagellate: Dinophysis sp. Several species were identificd and their scasonal distribution patterns are described. The origin of the blooms, from either coastal endemic or offshore populations, is considered.

Keywords : Dinophysis, seasonal distribution, French coast.

Manifestation saisonnière de Dinophysis sp. sur les côtes françaises entre 1983 et 1987.

Résumé

A partir de données hydrologiques et biologiques obtenues entre 1983 et 1987 sur les côtes françaises, et en particulier en Bretagne Sud, il a été possible de comparer différents paramètres pour tenter d'expliquer les variations saisonnières d'un dinollagellé toxique: Dinophjsis sp. Plusieurs espèces ont été identifiécs et les modalités de leur distribution sont décrites. Le problème de l'origine de ces efflorescences: populations côtières endémiques ou venant du large, est considéré.

Mots-clés : Dinophysis, distribution saisonnière, cỏtes françaises.

\section{INTRODUCTION}

Several outbreaks of Diarrhcic Shellfish Poisoning (DSP) have been reported in the European coastal waters since 1961. Initially, about 164 cases of diarrheic intoxications further to the consumption of musscls on the Dutch coastal area were attributed to the effects of a toxic alga, although the phytoplankion observed in the vicinity of mussels beds was considered as non toxic (Kat, 1979). Some years later, in 1976, 1979 and 1981 similar intoxications occurred along the Dutch coast and Dinophy'sis acuminata was suspected as the responsible toxic agent (Kat, 1983).
Other DSP outbreaks were reported by Tangen (1983) in the Oslo fjord (1971 and 1974) and, still in Norway, by Dahl and Yndestad (1985) during the 1984-1985 winter season. The responsible species were $D$. acuminata, and $D$. acuta, and many other countries have been confronted with that problem over the past 10 years: Spain, Denmark, France, Germany, still with several species of Dinophysis postulated as being the toxic agent (Durant-Clément et al., 1988; Fraga et al., 1984; Fraga and Sanchez, 1985; Lassus et al., $1985 a$ and $b$; Paulmier and Joly, 1985; Kat, pers. comm.). The toxic effects were, on a general basis, more thoroughly studied than the ecological features 
of Dinophysis blooms. A large amount of work has been done by Japanese investigators since Dinophy'sis fortii was identified in 1980 as the dinoflagellate responsible for DSP outbreaks which occurred along the Japanese coasts in 1976, 1978 and 1982. (Yasumoto et al., 1978, 1980) and since the diarrheic toxin was isolated and characterized by Murata et al. (1982) as a methyl-okadaĩc acid. Later on, Kumagai et al. (1986) demonstrated that the okadaic acid was one of the toxic components involved in DSP outbreaks in French, Dutch and Swedish mussels, whereas several toxins (DTX and PTX) had to be suspected in DSP cpidemia in Japan (Yasumoto et al., 1984).

Concerning the hydrological parameters correlated with Dinophysis blooms, a rew studies are available on European species (Kat, 1984; Lassus et al., 1985; Paulmicr and Joly, 1985; Dahl and Yndestad, 1985; Durand-Clément et al., 1988). It is assumed that all species studied (D. acuminata, D. acuta, D. sacculus) are neither correlated with physicochemicals parameters (e. g. nutrients) nor with any specific temperature/salinity patterns. Some corrclations may bc obscrved with low wind speeds, some earlier blooms of diatoms and, especially, the general coastal current systems. Migration occurs over a 24 hours cycle, with a typical diurnal spreading in the upper layers and ETM observations clearly indicate chloroplasts, in $D$. acuminata specimens, evidencing a conventional photosynthetic behaviour. Concerning $D$. fortii ecological features, comprehensive data can be found in Japanese literature (Ozaka, 1985; Igarashi, 1986; Iwasaki, 1986): every year, the distribution of this species along the Japanese coasts clearly indicates an extensive transport by oceanic currents from the west coast (Japan sea) to the north and north east coasts (Pacific ocean), with peak densities in June (seldom in excess of $10^{4} \mathrm{cell} / \mathrm{dm}^{3}$ ). The highest densities can be observed in small semi-closed bay systems where endemic bottom populations coexist in summer with oflshore introduced new populations. $D$. fortii is clearly differentiated from European Dinophysis by the need for a temperature/salinity pattern of $10-15^{\circ} \mathrm{C}$ and $33.0-33.5 \times 10^{-3}$ in order to observe a maximum growth.

This particular feature was used by Japanese investigators in a simple predictive mathematical model which has not yet been successfully tested over several years.

Some other predictive parameters are used (Igarashi, 1985; Ozaka, 1985) such as the summer extension of oceanic cold bottom currents along the north east coast (correlated with DSP levels in shellfish) and biological indicators such as other coincident dinoflagellate species (D. acuminata and Gonjaulax spinifera). However, the role and origin of trace elements as growing factors have not yet been clearly demonstrated in this interesting study: do they stimulate Dinophysis growth in cutrophicated bays or in some stratified offshore arcas with particular hydrological patterns?
In this paper an attempt is made to analyze these questions from data collected along the French coasts from 1983 to 1987.

\section{METHODS}

The Vilaine bay sampling grid was extented from 14 surface stations in 1983 to 17 in 1984, whereas in 1985,1986 and 1987 a North-South transect of 7 to 8 stations was set up in order to investigate phytoplankton and hydrological parameters at several depths: $1,3,5,10,20$ and $30 \mathrm{~m}$. Samples were collected twice a month or more during summer and monthly otherwise. The measured parameters were: temperature, salinity, dissolved inorganic nitrogen (DIN), dissolved inorganic phosphorus (DIP), silicates and dissolved oxygen. Phytoplankton cells preserved in acetic lugol were identified and counted with an inverted microscope, using the Utermöhl method. In 1986 and 1987, researches were conducted along the southern Brittany coastlines, using oceanographic vessels, and the $10 \mathrm{~m}$ surface layer was sampled for phytoplankton and hydrographic parameters (temperature and salinity) at $1,3,5$ and 10 m depths.

\section{RESULTS}

\section{General seasonal distribution pattern}

Every $y$ ear, for the period ranging from 1983 to 1987, the same distribution patterns, such as represented in figure 1 (data compiled from a phytoplankton national monitoring program)-are observed on the Atlantic and Channel coasts: maximum concentrations occur in June for southern Brittany and in July/August in Normandy (fig. 1). Along the Normandy coasts, and especially in the castern area of the Scine bay, Dinophysis cl acuminata was the dominant species, whereas along the Brittany coasts $D$. sacculus and probably some other species (D. nortegica and D. acuminata lachmanii, (Balech, pers. comm.) cocxist during blooms (fig. 2). It is rather difficult to suspect a transport by oceanic currents as this is actually the case in Japan for $D$. fortii, as all areas are generally affected at the same time.

Maximum cell concentration thresholds $\left(10^{4} / \mathrm{dm}^{3}\right.$ in the Vilaine bay and more than $10^{5} \mathrm{cell} / \mathrm{dm}^{3}$ in Antifer harbour) and relative DSP levels in farmed shelliish were the only obvious factors allowing any comparison to be made from year to year"between all contaminated arcas. No case of Dinophysis discoloured water was reported, even for concentrations in excess of $10^{5} \mathrm{cell} / \mathrm{dm}^{3}$, as this species was never reported as the dominant species among dinollagellate communities.

Several "critical areas" are nevertheless noticed: the bay of Douarnenez and the Vilaine bay for southern Brittany, and the Antifer harbour for Normandy, 

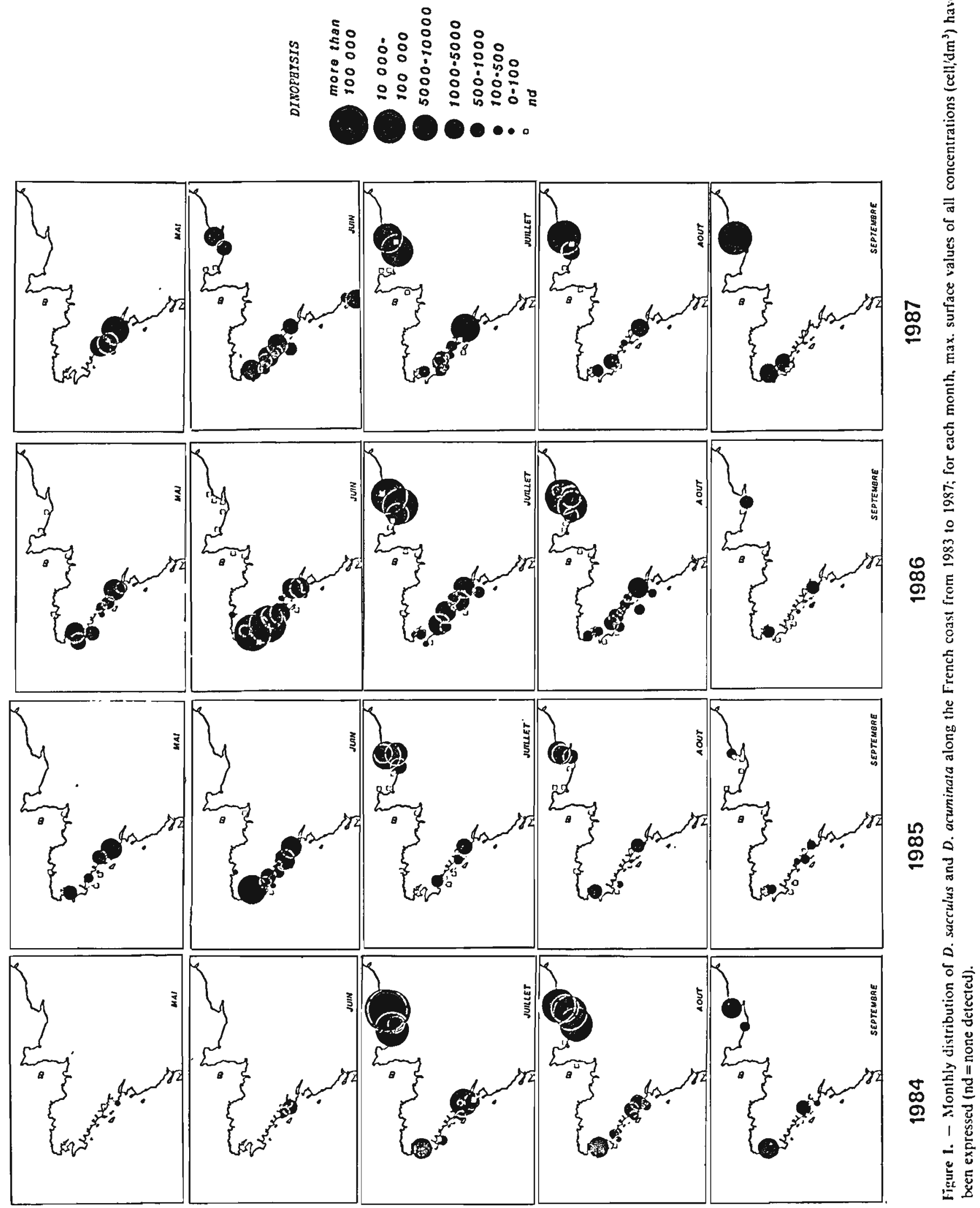

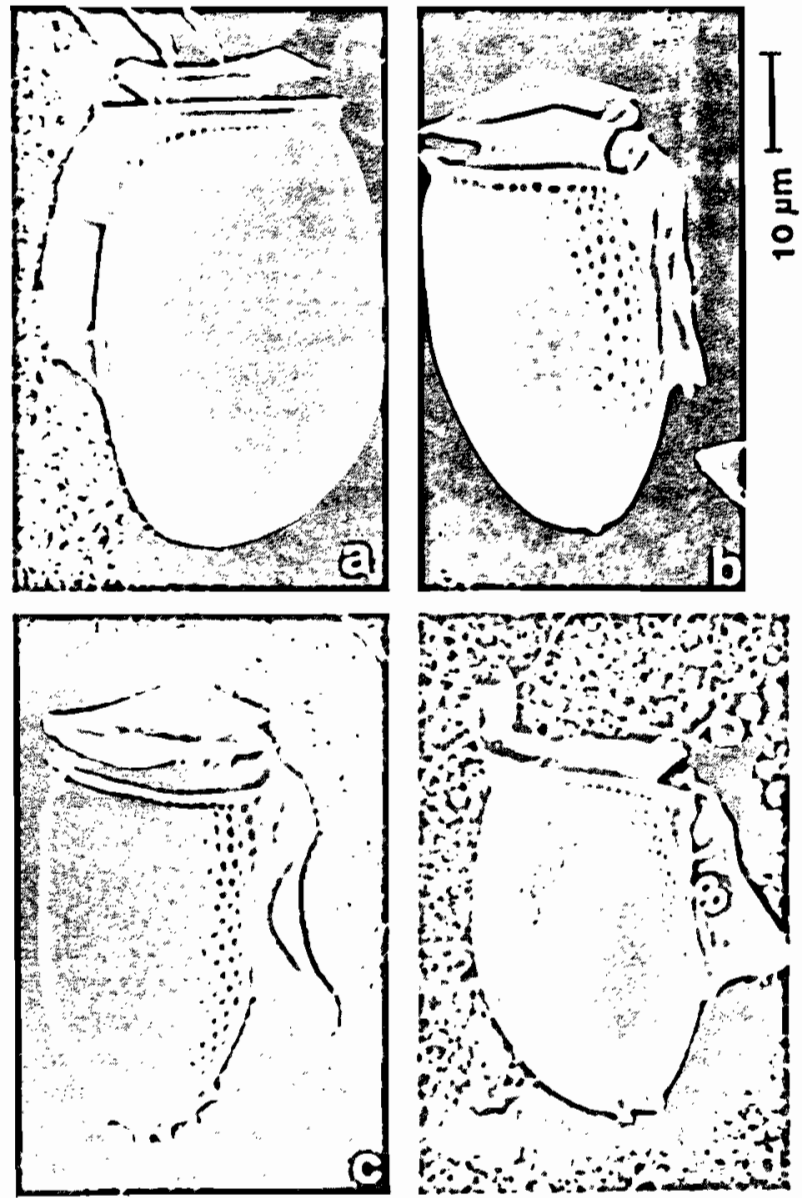

Figure 2. - Dinophysis of acuminata from the Normandy coast (Antifer), (a): lateral view, (b): Dinophysis sacculus from Vilaine bay, (c): $D$. sacculus from Douarnenez bay collected in 1986, (d): D. cf. nortegica collected in 1987 in Vilaine bay.

where the highest concentrations occurred, and where residual populations were still observed in late summer. On an other hand, in 1987, new areas were contaminated: the Aiguillon bay on the Atlantic coast, and the western Mediterranean coast.

\section{Distribution along the southern Brittany coast}

During an oceanographic survey cruise conducted in June 1986, samples of water in the top $10 \mathrm{~m}$ layer were analysed for phytoplankton in a study area comprised between Concarneau and île d'Yeu (fig. 3). The highest densities were observed down to $3 \mathrm{~m}$ depth in a highly stratified area situated in the south of river Loire estuary mouth. Despite thermal stratification was more important than the salinity gradient, significant ( $99 \%$ confidence limits) correlations of 0.66 and 0.57 respectively were found between the $\log$ of Dinophysis concentrations at 3 and $5 \mathrm{~m}$ depths and the difference of sca-water density from the surface down to $10 \mathrm{~m}$ depth. In June 1987 , the general patterns of Dinophysis distribution were different: concentrations were low and patchy, higher in the same stratified area but generally lower than in 1986. The result was that no correlation could be established with sea-water density, and despite a large DSP epidemia in May 1987 in the Aiguillon bay and neighbouring areas of Charentes-Maritimes (about 2000 cases of intoxication), the mean level of shellfish contamination for the whole southern Brittany coast proved to be low in June/July, and did not lead to a severe ban of shellfish marketing.

\section{Vilaine Bay}

A part from the general summer distribution pattern of Dinophysis sp. along the southern Brittany coasts, a "critical area" was studied between 1983 and 1987: the Vilaine bay successively suffered from extensive DSP epidemias in mussels in 1978, 1981, 1983 and 1986. Dinophysis was described as the toxic agent for the first time in 1983 (Alzieu et al., 1983; Lassus et al., 1985; Le Baut et al., 1985), and sporadic contamination also occurred in 1985 and 1987. This area is typically stratificd in summer (Langlois, 1984) and three sub-areas have been delineated by Mer (1986), using the cluster analysis to establish comparisons between the sampling stations, e. g.: an homogeneous area with dominance of Vilaine estuarine waters, an oceanic sub-area in the southern part of the bay, and an intermediate zone (fig. 4). The analysis of the data collected in 1983-1984 showed that Dinophysis blooms were detected after the decay of diatom discoloured waters (peak in June) but no relation could be established between Dinophysis concentrations and temperature/salinity patterns (Lassus et al., 1985). The hypothesis of stimulating factors released after the decay of diatoms was not verified during the 1986 Dinophysis bloom, as no diatom discoloured water was observed. In 1985 the Dinophysis sacculus vertical distribution pattern revealed a summer maximum concentration layer situated between 3 and $5 \mathrm{~m}$ water depth (table 1) similarly to the observations made later on in this area, and in oflshore waters during the 1986 cruise. Water column stability probably has an cffect on Dinophysis sub-surface concentrations as the decreasing rates observed in late June 1985 (fig. 5) actually coincided with strong west winds. A more comprehensive study of the vertical distribution pattern was conducted between April and September 1986 (fig. 6): maximum concentrations were confirmed during the period comprised between June and July. The south part of the bay is first contamined in April, whereas in September the residual populations are confined in the inner area of the bay. It is also interesting to note that the highest Dinophysis concentrations (in excess of $5000 \mathrm{cell} / \mathrm{dm}^{3}$ ) are of ten situated close to the bottom in the shallow waters of the bay. In that later case, it can be postulated that such relatively high concentrations result from physical accumulation processes rather than caused by an old 

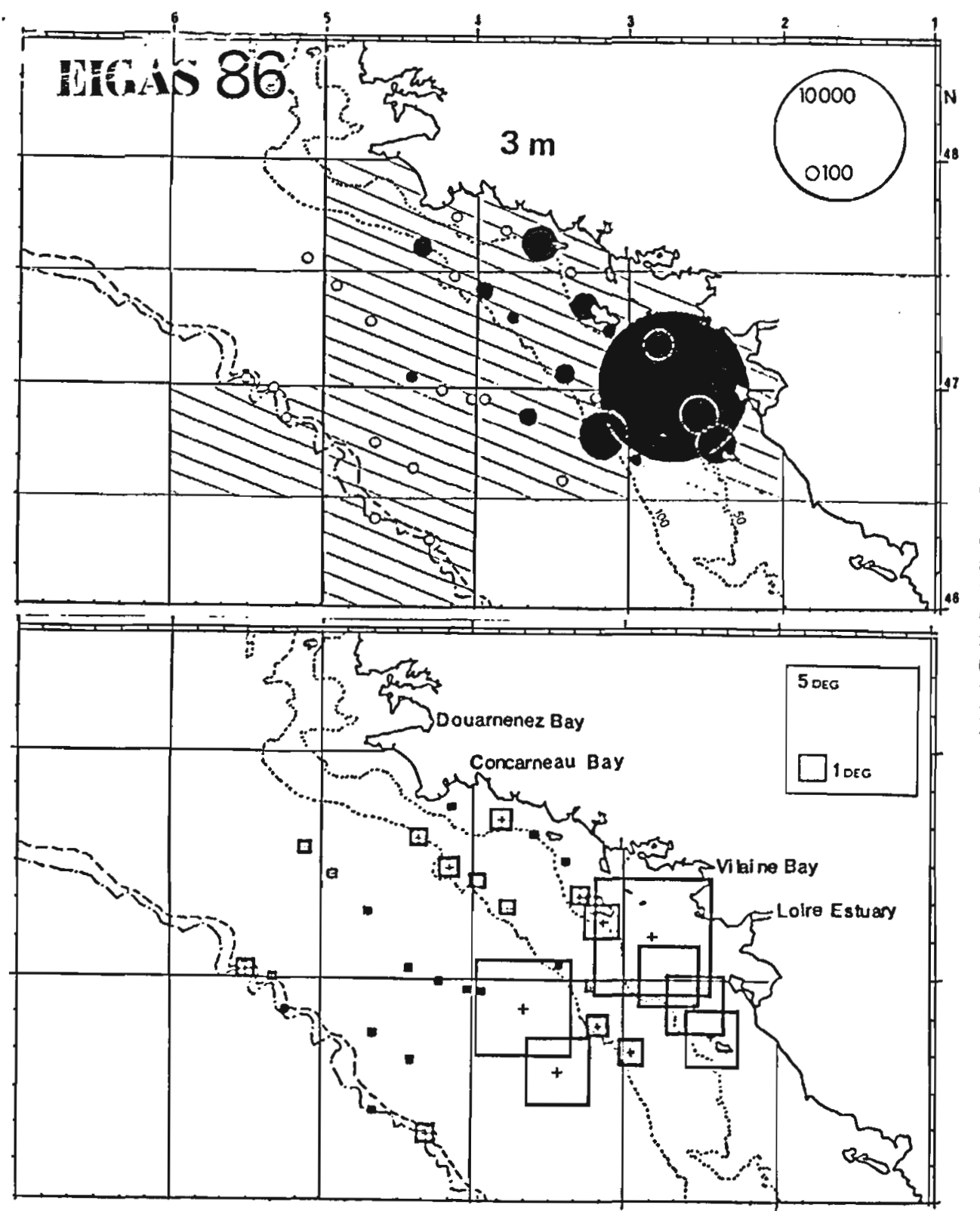

Figure 3. - Upper: Dinophysis concentrations (cell, $\mathrm{dm}^{3}$ ) in June 1986 (all species counted: D. sacculus, D. rotundata and $D$. skagi) at $3 \mathrm{~m}$ depth off southern Brittany (open circles indicate none detected). Lower: correlated thermal stratification in the same area (the squares are proportional to the temperature difference between the 1 and $10 \mathrm{~m}$ layers. The cruise is referred to as Eigas 86.

stage population sinking to the bottom. Such accumulation processes can be partly explained by a cyclonic current system in the inner part of the bay (De Nadaillac and Breton, 1985). From the data collected between 1983 and 1986 no clear evidence could be found as to a possible link cither with hydrological parameters, or with biological indicators such as Prorocentrum micans. It only appeared that no correlation could be established between log of Dinophysis concentrations and temperature, salinity or nitrates, and that a possible negative correlation with phosphates was found in 1983 and 1986, when peak Dinophy:sis blooms were observed. A correlation with Prorocentrum blooms was only found in 1983 and, apparently, could not be used as a "predictive parameter" for the next years.

A last point was studied: the inlluence of water stability $\left({ }^{*}\right)$ on Dinophysis concentrations. From data related to the 1983 and 1986 blooms, it appears (fig. 7) that the increases in stability index correspond to increasing Dinophysis concentrations, sometimes with a short time lag.

(*) Expressed as $\mathrm{E}-10^{-3} d \mathrm{~S} ; \mathrm{dZ}$, with $d \mathrm{~S}$ : difference between surlace and bottom density, and $d Z$ : depth. 


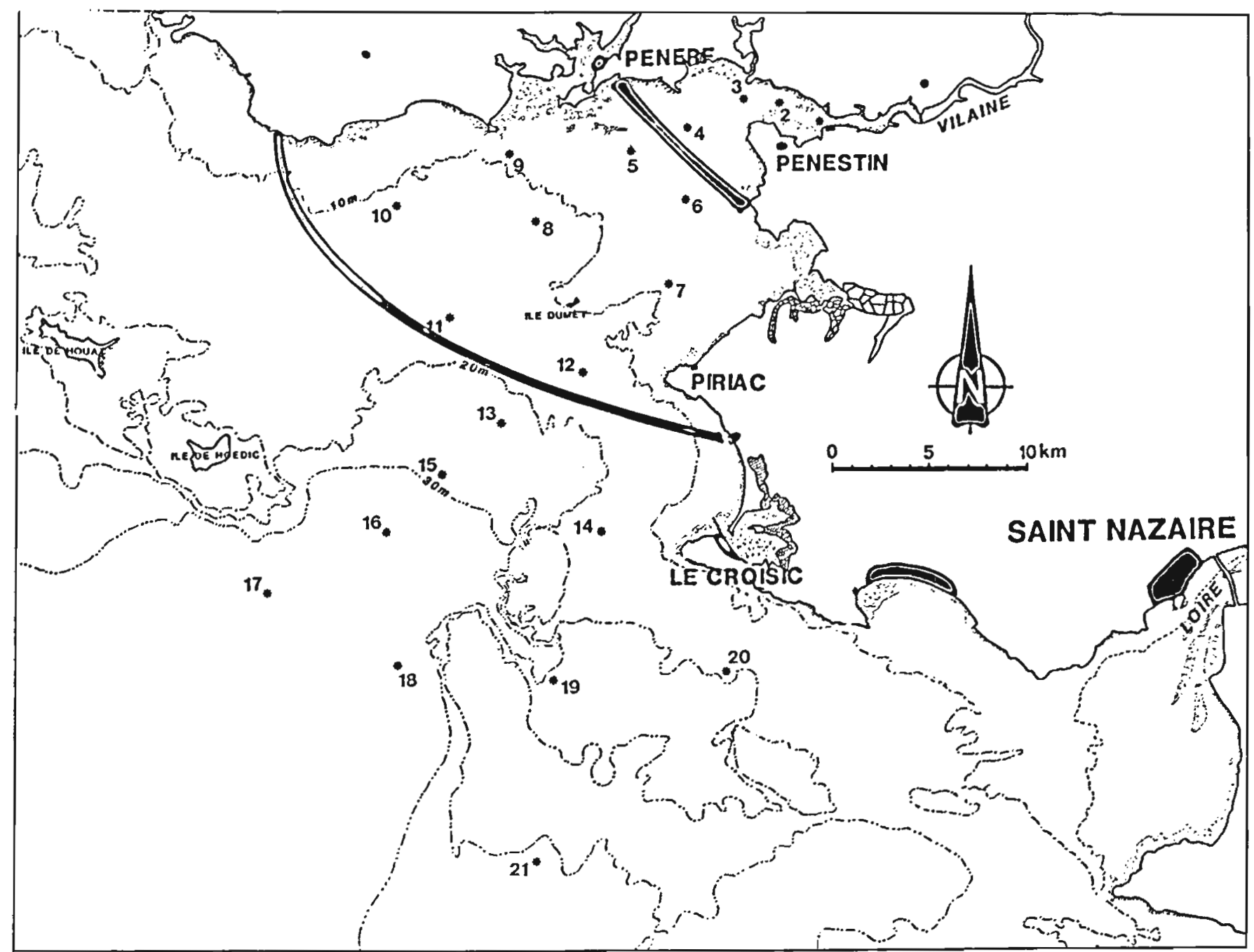

Figure 4. - Vilaine bay, sampling grid and sub areas as determined by Mer (1976) from a cluster analysis of hydrological parameters and chlorophyll at each station. Stations 1-4: estuarine zone; stations 5-12: intermediate zone; stations 13-21: oceanic zone.

Table 1. - Arithmetic mean $(\bar{x})$ of Dinophysis concentrations at different depths during summer 1985 for all sampled stations $n=$ number of cell counts, $r \%=$ variation of standard deviation $(\mathrm{S} / \bar{x})$.

\begin{tabular}{crrr}
\hline Depths & $n$ & $\bar{x}$ & $r \%$ \\
\hline $0 \mathrm{~m}$ & 36 & 593 & 117 \\
$1 \mathrm{~m}$ & 109 & 605 & 110 \\
$3 \mathrm{~m}$ & 90 & 1239 & 157 \\
$5 \mathrm{~m}$ & 88 & 1063 & 147 \\
$10 \mathrm{~m}$ & 57 & 435 & 179 \\
$20 \mathrm{~m}$ & 24 & 229 & 105 \\
$30 \mathrm{~m}$ & 15 & 104 & 302 \\
\hline
\end{tabular}

\section{DISCUSSION}

Despite the fact several species of toxic Dinophysis produce DSP outbreaks almost every year along the
French coasts, such bloom events cannot be assimilated to "red tides" or "exceptionnal blooms" as the maximum concentrations seldom exceed $5 \times 10^{3} \mathrm{cell} / \mathrm{dm}^{3}$. This feature, makes that it is not easy to find an hydrological parameter which could be used as a predictive or discriminant factor.

Nevertheless, on the basis of the data collected over the period ranging from 1983 through 1987 during field observations (culture assays of Dinophysis revealed unsuccessful, Durand-Clément et al., 1988), several points can be outlined. First, despite the important yearly amount of $\mathrm{N}-\mathrm{NO}_{3}$ discharged in certain areas such as the Vilaine bay (11000 t/year), no evidence of any relationship with summer Dinophysis blooms can be demonstrated. Now, the general pattern of Dinophysis distribution along the French coasts reveals different seasonal peak values, depending on the dominant species: $D$. acuminata in July along the 

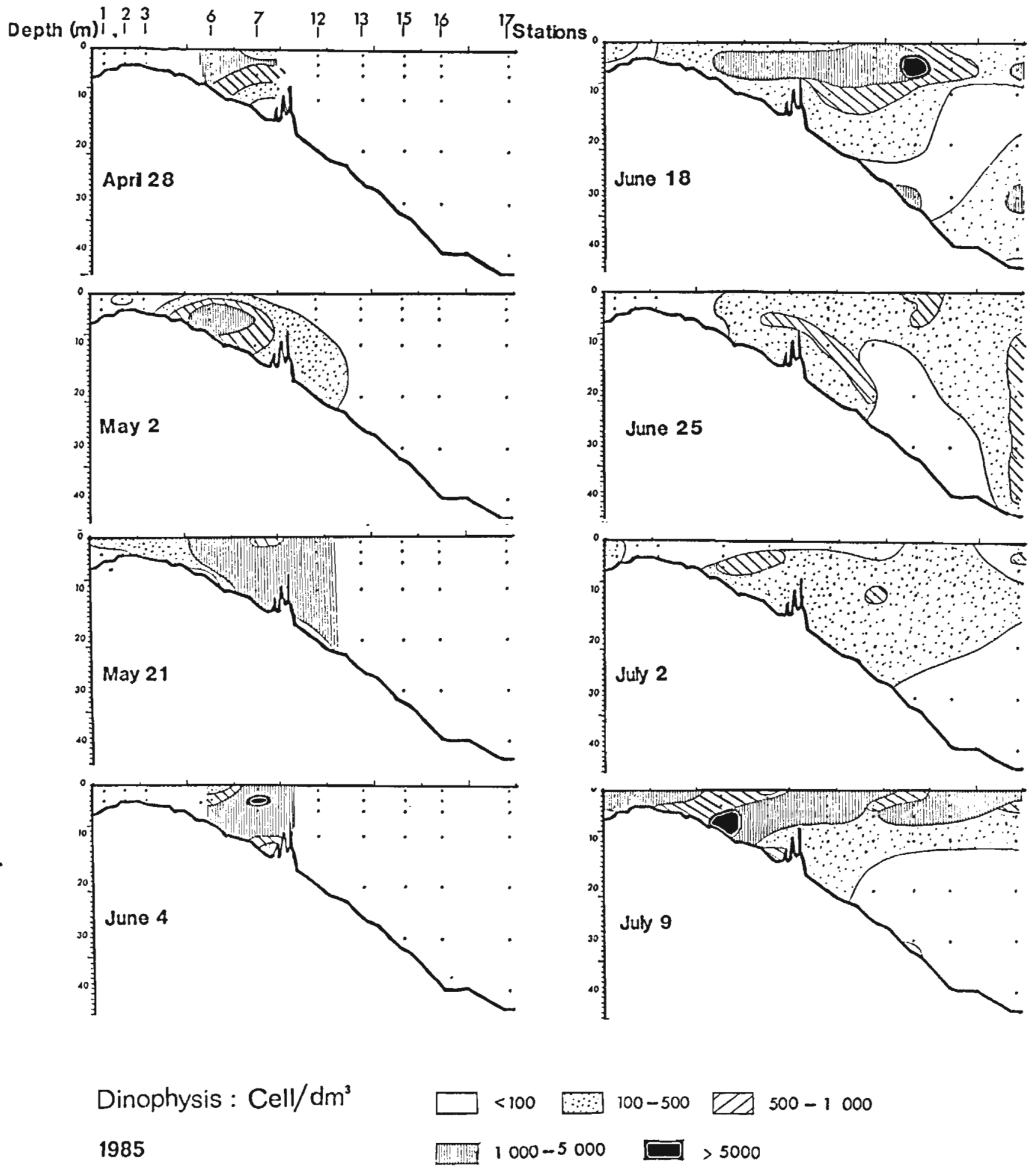

Figure 5. - Vertical distribution of Dinophysis sacculus in Vilaine bay in June and July 1985.

Channel coast, $D$. sacculus and other species in June along the Atlantic coasts. If transport of offshore populations by coastal currents to inshore semi-closed systems most probably occurs, no wide dissemination of these species due to oceanic currents can be exploited, as this is the case for $D$. fortii distribution patterns in Japanese waters. As in offshore statified areas, a correlation with the water stability index can 

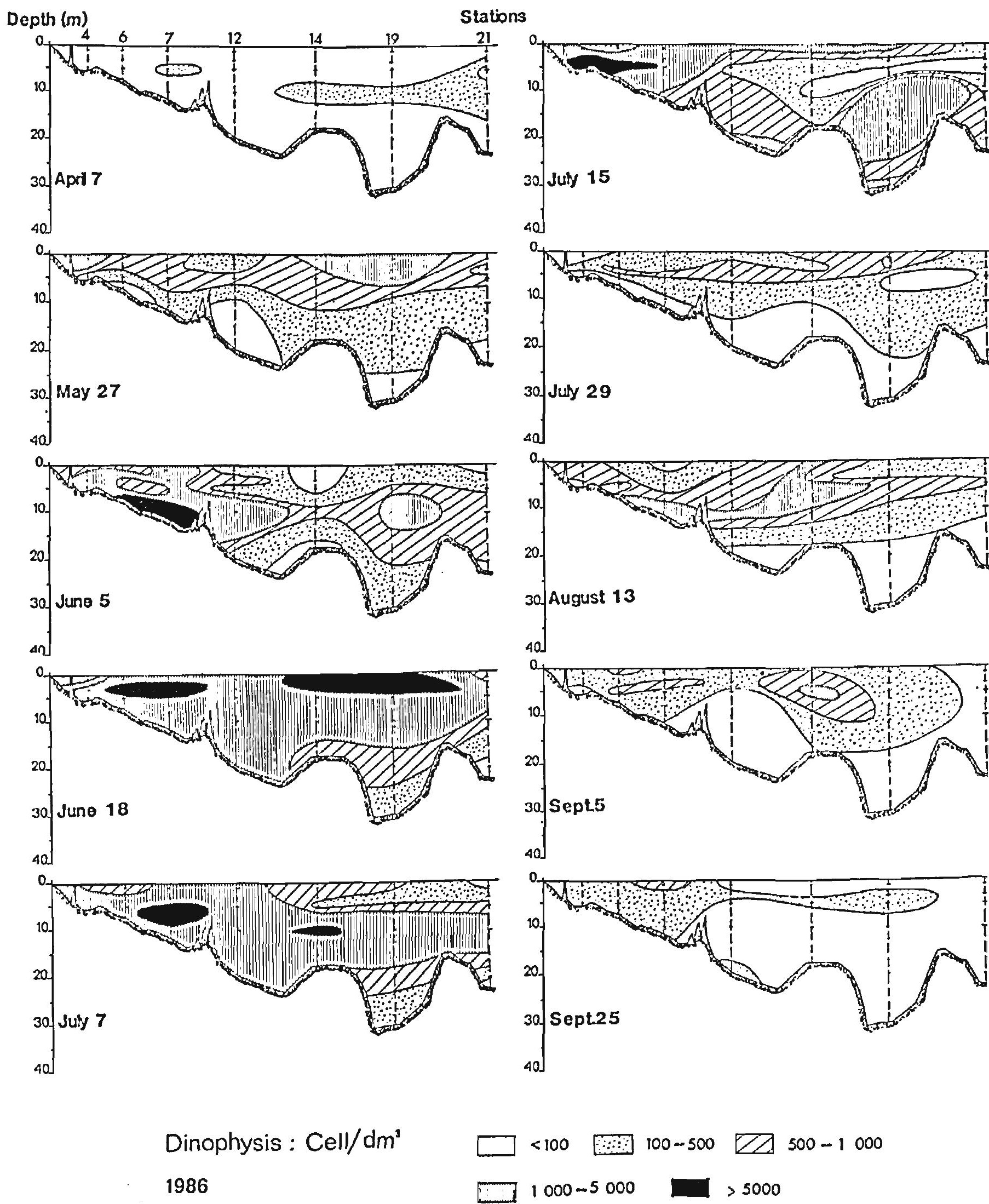

Figure 6. - Vertical distribution of Dinophysis sacculus in Vilaine bay from April to September 1986. 

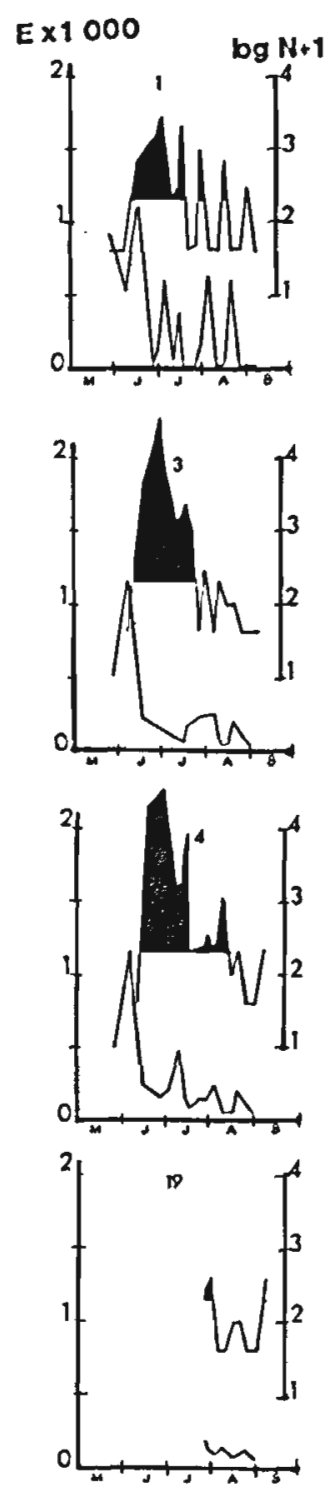

1983
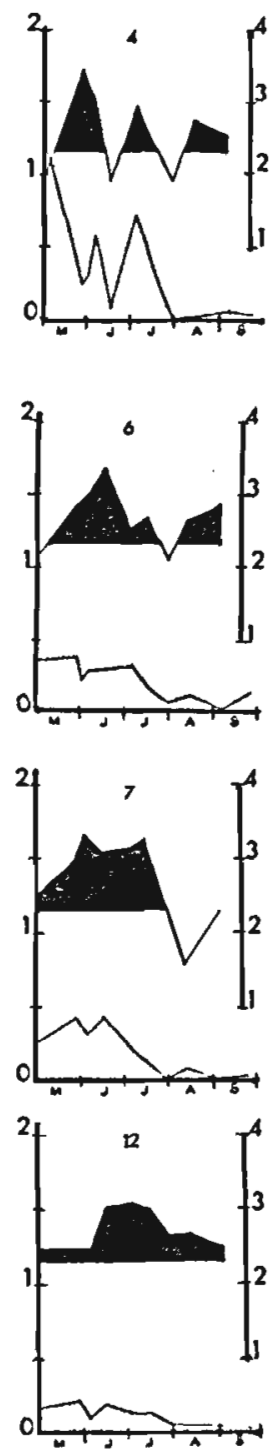

1986

Figure 7. - Comparative evolution of the log of Dinophysis concentration and of stability index $E$ (cf. text) in Vilaine bay during the summers of 1983 and 1986. Dark areas correspond to cell

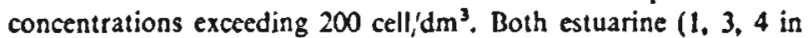
$1983 ; 4,6,7$ in 1986) and oceanic (19 in 1983; 12 in 1986) stations are investigated.

be observed in bay systems (fig. 7) during the years of highest blooms. It is obvious that if such a factor promotes the physical sub-surface accumulation of Dinophysis, other factors most probably behave as "initiating factors". Phosphates are postulated as the limiting factor for phytoplankton production in the Vilaine bay (Clément et al., 1988) an could be related to extensive blooms of Dinophysis in such eco-systems, but if summer coastal populations originate from

offshore populations, other triggering factors have to be studied in critical stratified areas: the high Dinophysis concentrations observed in 1986 in the south part of river Loire estuary mouth for one third constituted of dividing cells. Finally, a possible biological indicator such as Prorocentum micans cannot be used as a predictive factor for a continuous monitoring survey.

\section{CONCLUSION}

From the hydrological and biological data collected in the Vilaine bay as well as off the coasts of Southern Brittany between 1983 and 1987, it appears that blooms of Dinophysis sp. are essentially related to physical offshore processes like thermal stratification and water colum stability, and depend on general coastal current systcm. Some secondary processes may act as promoting factors in bays and estuaries, but nutrients levels as triggering factors are unprobable. The absence of any significant correlation with simple parameters (temperature, salinity, nitrates) constitutes the real difficulty for developing a predictive model, and further information is needed as to the behaviour of this dinoflagellate: winter crop, migration, effect of grazing by zooplankton.

\section{REFERENCES}

Clément J. C., M. Durand-Clément, B. Queguiner, P. Treguer, P. Maggi, P. Lassus, 1988. Phytoplancton et conditions hydrochimiques dans un ćcosystème littoral stratifié (baic de Vilaine, France). Oceanol. Acta, in press.

Dahl E., M. Yndestad, 1985. Diarrhetic shellfish poisoning (DSP) in Norway in the autumn 1984 related to the occurrence of Dinophysis sp. In: Toxic Dinoflagellates, D. M. Anderson, A. W. White, D. G. Baden Eds., Elsevier, North-Holland, 495.500.

De Nadaillac G., M. Breton, 1985. Les courants en baie de Vilaine présentation et interprétation des données. Rapp. interne IFREMER-DER O-85-03-EL, 73 p.

Durand-Clément M., J.-C. Clément, A. Moreau, N. Jeanne, S. Puiseux-Dao, 1988. New ecological and ultrastructural data on the dinollagellate Dinophysis sp. from the French coast. Mar. Biol., 97, 37-44.

Fraga S., J. Marino, I. Bravo, A. Miranda, M. J. Campos, F. J. Sanchez, E. Costas, J. M. Cabanas, J. Blanco, 1984. Red tides and shellfish poisoning in Galicia (NW Spain). ICES, Special meeting on causes, dynamics and effects of exceptional marine blooms and related events. Copenhagen, 4.5 Oct. 1984, C: 5,5 p.

Fraga S., F. J. Sanchez, 1985. Toxic and potentially toxic dinonagellates found in Galician rias (NW Spain). In: Toxic dinollagellates, Anderson D. M., White A. W., D. G. Baden, Eds., Elsevier, North-Holland, 495-500.

Igarashi T., 1985. Sanriku coasts. In: Biology and ccology of shellfish poisoning plankton, Fukuyo Ed., Bull. Jap. Assoc. Scl. Fish., Fish. ser., 56, (in Japanese) 71-81. 
Igarashi T., 1986. Occurrence of Dinophysis fortit, a dinollagellate responsible for diarrhetic shellfish poisoning at Kesennuma bay. Bull. Tohoku. Reg. Fish. Res. Lab., Tohokusuiken kenpo, 48, 137-144.

Iwasaki J., The mechanism of mass occurrence of Dinophysis fortil along the coast of Ibaraki Prefecture. Ibid., 48, $125-136$.

Kat M., 1979. The occurrence of Prorocentrum species and coincidental gastro-intestinal illness of mussel consumers. In: Toxic Dinoflagellate blooms, D. Taylor, H. H. Seliger Eds., Elsevier, North-Holland, 215-220.

- 1983. Dinophysis acuminata blooms in the Dutch coastal area related to diarrhetic mussel poisoning in the Dutch Waddensea. Sarsia, 68, 81-84.

- 1984. Diarrhctic mussel poisoning. Measures and consequences in the Netherlands. ICES, Special meeting on causes, dynamics and effects of exceptional marine blooms and related events. Copenhagen, 4-5 Oct., 1984, C: $3,10 \mathrm{p}$.

Krogh P., L. Edler, E. Graneli, U. Nyman, 1985. Outbreak of diarrheic shellfish poisoning on the west coast of Sweden. In: Toxic Dinollagellates D. M. Anderson, A. W. White, D. G. Baden Eds., Elsevier, North-Holland, 501-504.

Kumagai M., T. Yanagi, M. Murata, T. Yasumoto, M. Kat, P. Lassus, J. A. Rodriguez-Vasquez, 1986. Okadaic acid as the causative toxin of Diarrhetic Shellfish Poisoning in Europe. Agric. Biol. Chem., 50, 2853-2857.

Lassus P., M. Bardouil. I. Truquet, P. Truquet, C. Le Baut, M. J. Pierre, 1985a. Dinophysis acuminata 1983 and 1984 distribution and toxicity along south Brittany coasts (France) and correlation with hydrological parameters. In: Toxic Dinoflagellates D. M. Anderson, A. W.
White, D. G. Baden Eds., Elsevier, North-Holland, 159. 162.

Lassus P., A. G. Martin, P. Maggi, J.-P. Berthomé, A. Langlade, E. Bachère, $1985 b$. Extension du dinoflagellé Dinophysis acuminata en Bretagne Sud et conséquences pour les cultures marines. Rer. Trat. Inst. Pêches marit., 47, 122-133.

Mer G., 1986. Traitement mathématique des données hydrologiques acquises en baie de Vilaine en 1984 et 1985. Rapp. interne IFREMER-DERO-86-08-MR, $71 \mathrm{p}$.

Murata M., M. Shimatani, H. Sugitani, Y. Oshima, T. Yasumoto, 1982. Isolation and structural elucidation of the causative toxin of the diarrhetic shellfish poisoning. Bull. Jap. Soc. Sci. Fish., 48, 549-552.

Ozaka Y., 1985. Mutsu bay. In: Biology and ecology of Shellsish poisoning plankton, Fukuyo Ed., Bull. Jap. Assoc. Sci. Fish., Fish. ser., 56, (in Japanese), 59-70.

Paulmicr G., J.-P. Joly, 1985. Manifestations de Dinophysis acuminata sur le littoral français. Rev. Trav. Inst. Pêches. marit., 47, 149-157.

Tangen K., 1983. Shellish poisoning and the occurrence of potentially toxic dinoflagellates in Norwegian waters. Sarsia, 68, 1-7.

Yasumoto T., Y. Oshima, M. Yamaguchi, 1978. Occurrence of a new type of shellfish poisoning in the Tohoku distric. Bull. Jap. Soc. Sci. Fish., 44, 1249-1255.

Yasumoto T., Y. Oshima, W. Sugawara, Y. Furuyo, H. Oguri, T. Igarashi, N. Fujita, 1980. Identification of Dinophysis fortii as the causative organism of diarrhetic shellish poisoning. Ibid., 46, 1405-1411.

Yasumoto T., M. Murata, Y. Oshima, G. K. Matsumoto, J. Clardy, 1984. Diarrhetic Shellfish Poisoning. In: Seafood Toxins, E. P. Ragclis Ed., Am. Chem. Soc. Symp. ser., 262, 207-214. 